\title{
Safety and efficacy of noninvasive ventilation in patients with blunt chest trauma: a systematic review
}

\author{
Abhijit Duggal ${ }^{1}$, Pablo Perez ${ }^{2}$, Eyal Golan ${ }^{3,4}$, Lorraine Tremblay ${ }^{2,3,5}$ and Tasnim Sinuff ${ }^{2,3^{*}}$
}

\begin{abstract}
Introduction: This systematic review looks at the use of noninvasive ventilation (NIV), inclusive of noninvasive positive pressure ventilation (NPPV) and continuous positive pressure ventilation (CPAP), in patients with chest trauma to determine its safety and clinical efficacy in patients with blunt chest trauma who are at high risk of acute lung injury (ALI) and respiratory failure.

Methods: We searched the MEDLINE, EMBASE and Cochrane Central Register of Controlled Trials (CENTRAL) databases. Pairs of reviewers abstracted relevant clinical data and assessed the methodological quality of randomized controlled trials (RCTs) using the Cochrane domain and observational studies using the NewcastleOttawa Scale.

Results: Nine studies were included (three RCTs, two retrospective cohort studies and four observational studies without a comparison group). There was significant heterogeneity among the included studies regarding the severity of injuries, degree of hypoxemia and timing of enrollment. One RCT of moderate quality assessed the use of NPPV early in the disease process before the development of respiratory distress. All others evaluated the use of NPPV and CPAP in patients with blunt chest trauma after the development of respiratory distress. Overall, up to $18 \%$ of patients enrolled in the NIV group needed intubation. The duration of NIV use was highly variable, but NIV use itself was not associated with significant morbidity or mortality. Four low-quality observational studies compared NIV to invasive mechanical ventilation in patients with respiratory distress and showed decreased ICU stay (5.3 to 16 days vs 9.5 to 15 days), complications (0\% to $18 \%$ vs $38 \%$ to $49 \%$ ) and mortality (0\% to $9 \%$ vs $6 \%$ to $50 \%)$ in the NIV group.

Conclusions: Early use of NIV in appropriately identified patients with chest trauma and without respiratory distress may prevent intubation and decrease complications and ICU length of stay. Use of NIV to prevent intubation in patients with chest trauma who have ALI associated with respiratory distress remains controversial because of the lack of good-quality data.
\end{abstract}

\section{Introduction}

Management of patients with blunt chest trauma focuses on interventions such as the stabilization of fractures, pulmonary toilet, effective physiotherapy, and early and adequate pain control [1,2] These patients are at high risk for developing respiratory failure [3], with reports of up to $20 \%$ of patients with blunt chest trauma developing acute lung injury (ALI) or acute respiratory

\footnotetext{
* Correspondence: Taz.sinuff@sunnybrook.ca

${ }^{2}$ Department of Critical Care Medicine, Sunnybrook Health Sciences Centre and University of Toronto, Bayview Avenue, Toronto, ON, M4N 3M5, Canada Full list of author information is available at the end of the article
}

distress syndrome (ARDS) [1]. Intubation rates range from $23 \%$ to $75 \%$ and depend on the severity of the trauma, the degree of the underlying lung disease, and the intensity of initial management and monitoring $[1,4]$. The use of positive pressure ventilation has decreased the overall morbidity and mortality associated with blunt chest trauma [3], but endotracheal intubation and mechanical ventilation is associated with a high risk of nosocomial pneumonia and prolonged mechanical ventilation [5].

The role of noninvasive ventilation (NIV), which we consider to be either continuous positive airway pressure

\section{C) Biomed Central}


(CPAP) or noninvasive positive pressure ventilation (NPPV), for the management of patients with blunt chest trauma has not been established [5,6]. Although the safety of both CPAP and NPPV has been assessed in a number of observational studies in patients with blunt thoracic injuries [7-10], the evidence regarding the use of NIV in this setting is inconsistent [6]. Data derived from large multicenter trials evaluating NIV use in hypoxemic patients is not generalizable to these patients, as these trials included few trauma patients [11]. Two recent guidelines have offered a "no recommendation" or a "low-grade recommendation" for the use of NIV in blunt chest trauma [12,13]. However, these guidelines do not include the totality of the available data for this clinical condition.

The objective of this systematic review was to assess the current evidence regarding the use of NIV for patients with blunt thoracic trauma, to identify the most appropriate time to implement NIV and the safety of its use.

\section{Methods}

\section{Data sources, searches and study selection}

We searched the MEDLINE (1946 through June 2012), EMBASE (1980 through June 2012) and Cochrane Central Register of Controlled Trials (CENTRAL) databases using the search terms for NIV and blunt chest trauma (see Additional File 1 for the complete search strategy). Reference lists of retrieved articles and personal files were also searched.

We included published studies in any language, regardless of study design, that reported on clinical outcomes (for example, rate of endotracheal intubation, mortality) in patients with blunt chest trauma who were managed with NIV. There were no age restrictions. We also included case series and cohorts with no comparison groups to look at the safety of NIV in this patient setting. We excluded case reports, qualitative studies and economic analyses.

For the purpose of this systematic review, we defined noninvasive ventilation as the use of any degree of positive end-expiratory pressure or pressure support applied by facemask, helmet mask or nasal prongs. Thus, studies using CPAP or NPPV were included. Blunt chest trauma was defined as the presence of pulmonary contusions, rib fractures and flail chest or sternal fractures. The severity of injury was evaluated based on the Injury Severity Score (ISS) or the Thoracolumbar Injury Classification and Severity Score [14,15]. We ascertained the presence of acute hypoxemia using the partial pressure of arterial oxygen to the fraction of inspired oxygen ratio $\left(\mathrm{PaO}_{2}\right.$ : $\mathrm{FiO}_{2}$ ) of $300 \mathrm{mmHg}$ or less (for ALI) or $200 \mathrm{mmHg}$ or less (for ARDS) (16). Two investigators (AD and PP) independently and in duplicate completed the literature search and located potentially eligible articles.

\section{Data extraction and quality assessment}

Two investigators (AD and PP) independently extracted the following data: authors, year and country of publication, ICU type, study design, inclusion and exclusion criteria, number of patients included, severity of hypoxemia and severity of injury (chest and overall trauma). We reviewed clinically relevant outcomes. The primary outcome of interest was the duration of ventilation in patients undergoing NIV compared to mechanical ventilation. Secondary outcomes included in-hospital mortality, ICU and hospital length of stay, development of nosocomial infections and development of any barotrauma. We assessed the use of NIV for ventilatory support in the patients who developed hypoxemic respiratory failure and ARDS and compared it with endotracheal intubation and mechanical ventilation. We also looked at the use of NIV compared to high-flow oxygen through facemask to determine the need for mechanical ventilation. We extracted safety data, including rate of NIV failure, associated mortality, nosocomial infection and barotrauma.

To assess the methodological quality of the included randomized controlled trials (RCTs), we followed the recommendations outlined in the Cochrane Handbook for Systematic Reviews of Interventions (domain-based evaluation of seven components) [17]. To assess the methodological quality of the included observational studies, we used the Newcastle-Ottawa Scale (point-based evaluation of the eight components). We modified the Newcastle-Ottawa Scale to look at the methodological quality of the case series and cohort studies without comparison groups by developing a six-point scale [18].

\section{Data synthesis}

We could not combine the data from any of the studies because of the clinical heterogeneity that existed during the time period of the intervention as well as the differences in patient selection criteria, severity of injury and comparison groups.

\section{Results}

\section{Study selection}

The initial search strategy identified 20 potentially eligible studies (Figure 1). We excluded 11 studies for the following reasons: six studies did not report any clinical outcomes, three were case reports and two were review articles (Additional File 2). Nine studies met our inclusion criteria. Three were RCTs $[6,20,21]$, two were retrospective cohort studies $[5,19]$ and four were observational studies [7-10].

\section{Study characteristics}

We report the main characteristics of the nine included studies in Table 1. Three main groups of studies were included. (1) Hernandez et al. evaluated early use of 


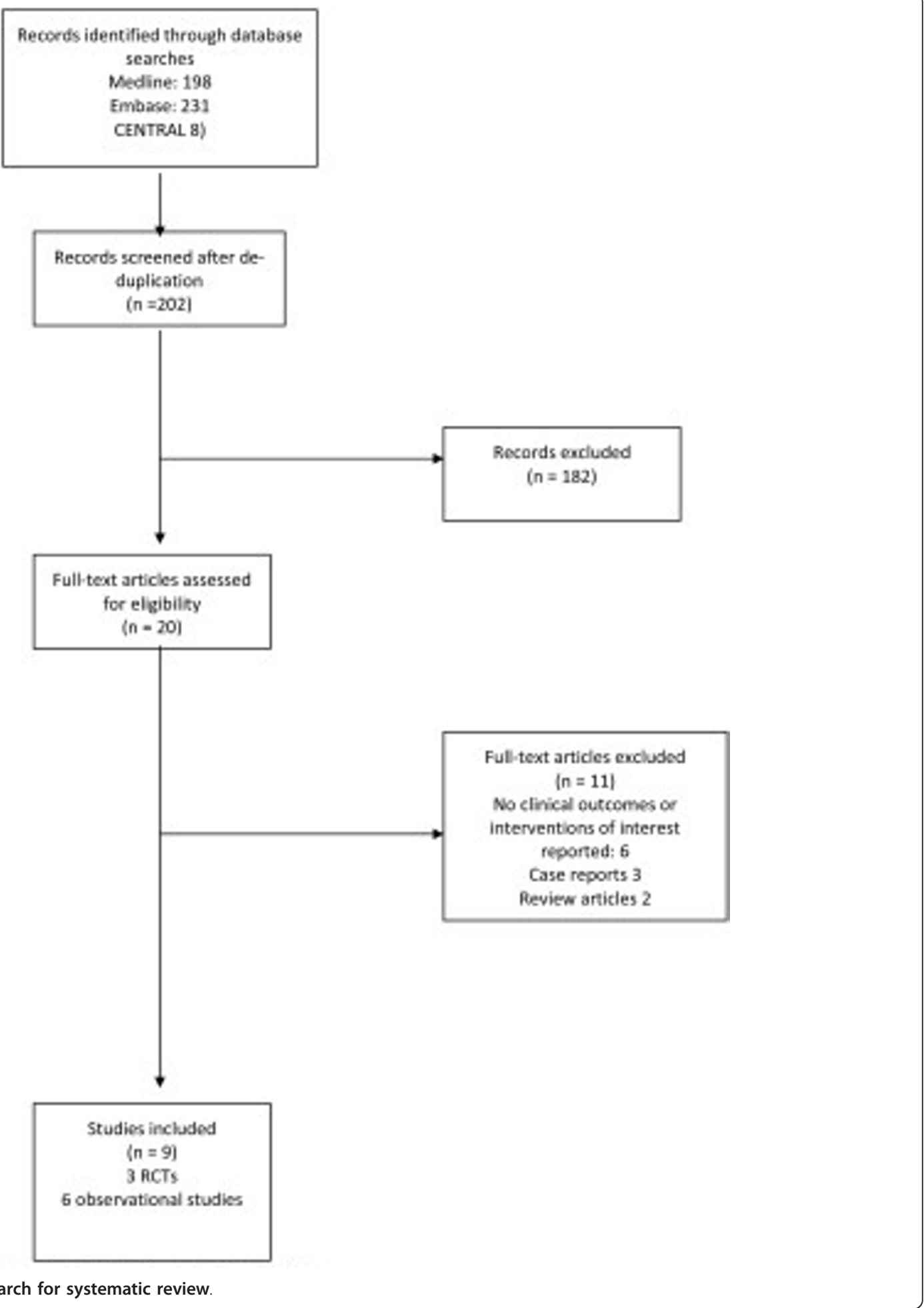

Figure 1 Literature search for systematic review.

NIV as compared to high-flow oxygen in patients with hypoxemia with or without signs of any respiratory distress within the first $8 \mathrm{~h}$ of presentation to the emergency room or ICU [6]. (2) Four studies evaluated patients late in their course of respiratory failure
[5,19-21]. These studies, in which NIV was introduced following the development of respiratory distress, compared the use of NIV to prevent intubation with early intubation. (3) Another four studies, which did not include a comparator group, assessed the safety of CPAP and NPPV 


\section{Table 1 Study characteristics. ${ }^{a}$}

\begin{tabular}{|c|c|c|c|c|c|c|}
\hline Study (design) & $\begin{array}{l}\text { Patients }(n) / \\
\text { country }\end{array}$ & $\begin{array}{l}\text { Study } \\
\text { intervention }\end{array}$ & $\begin{array}{l}\text { Control } \\
\text { intervention }\end{array}$ & $\begin{array}{l}\text { Severity of } \\
\text { hypoxemia }\end{array}$ & Quantification of severity of chest injury & Strategy for pain control \\
\hline \multicolumn{7}{|c|}{ I. Early interventions: CPAP/NPPV compared to supplemental oxygen } \\
\hline $\begin{array}{l}\text { Hernandez et al. (2010) } \\
\text { (RCT) }\end{array}$ & 50/Spain & NPPV & $\begin{array}{l}\text { High-flow } \\
\text { oxygen }\end{array}$ & $\begin{array}{l}\mathrm{PaO}_{2} / \mathrm{FiO}_{2} \leq 200 \text { for } \\
>8 \mathrm{~h}\end{array}$ & $\begin{array}{l}\text { Thoracic AIS, ISS, lung contusions/quadrant, thoracolumbar } \\
\text { vertebral trauma, flail chest }\end{array}$ & $\begin{array}{l}\text { Epidural analgesia (bupivacaine } \\
\text { and fentanyl) } \\
\text { Remifentanil infusion }\end{array}$ \\
\hline \multicolumn{7}{|c|}{ II. Late interventions: CPAP/NPPV after development of respiratory distress } \\
\hline $\begin{array}{l}\text { Xirouchaki et al. (2004) (case } \\
\text { series) }\end{array}$ & 22/Greece & NPPV & None & $\mathrm{PaO}_{2} / \mathrm{FiO}_{2} \leq 140$ & AIS, ISS & $\begin{array}{l}\text { Epidural analgesia } \\
\text { IV analgesia (not specified) }\end{array}$ \\
\hline $\begin{array}{l}\text { Tanaka et al. (2001) (case } \\
\text { series) }\end{array}$ & 59/Japan & CPAP & None & Not Reported & AIS, ISS, flail chest & Epidural analgesia (not specified) \\
\hline Walz et al., 1998 (case series) & 30/Germany & CPAP & None & $\mathrm{PaO}_{2} \leq 70$ & $\begin{array}{l}\text { Isolated or accompanying chest trauma on one or both } \\
\text { sides }\end{array}$ & $\begin{array}{l}\text { Epidural analgesia } \\
\text { Intercostal nerve blocks } \\
\text { IV analgesia }\end{array}$ \\
\hline $\begin{array}{l}\text { Hurst et al. (1985) (case } \\
\text { series) }\end{array}$ & 33/USA & CPAP & None & $\begin{array}{l}\mathrm{PaO}_{2} / \mathrm{FiO}_{2}<150 \text { or } \\
\mathrm{PaO}_{2}<65\end{array}$ & $\begin{array}{l}\text { Chest trauma (lung contusions, rib fractures) } \\
\text { No severity score used }\end{array}$ & Not specified \\
\hline \multicolumn{7}{|c|}{ III. Patient safety assessment: CPAP/NPPV compared to mechanical ventilation after development of respiratory distress } \\
\hline Gunduz et al. (2005) (RCT) & 43/Turkey & CPAP & $\begin{array}{l}\text { Mechanical } \\
\text { ventilation }\end{array}$ & $\mathrm{PaO}_{2} / \mathrm{FiO}_{2} \leq 300$ & $\begin{array}{l}\text { TTSS, five or more rib fractures in a row, three or more } \\
\text { segmental rib fractures, flail chest }\end{array}$ & $\begin{array}{l}\text { Morphine patient Controlled } \\
\text { analgesia }\end{array}$ \\
\hline $\begin{array}{l}\text { Bolliger and Van Eeden } \\
\text { (1990) (RCT) }\end{array}$ & $\begin{array}{l}\text { 69/South } \\
\text { Africa }\end{array}$ & CPAP & $\begin{array}{l}\text { Mechanical } \\
\text { ventilation }\end{array}$ & $\mathrm{PaO}_{2} / \mathrm{FiO}_{2} \geq 150$ & ISS, more than three rib fractures, pulmonary contusion & $\begin{array}{l}\text { Lumbar epidural analgesia } \\
\text { (buprenorphine) } \\
\text { Intercostal nerve blocks }\end{array}$ \\
\hline $\begin{array}{l}\text { Vidhani et al. (2001) } \\
\text { (retrospective cohort) }\end{array}$ & 75/Australia & NPPV & $\begin{array}{l}\text { Mechanical } \\
\text { ventilation }\end{array}$ & $\begin{array}{l}\mathrm{PaO}_{2}<65 \text { or } \mathrm{PaO}_{2} / \\
\mathrm{FiO}_{2} \leq 300\end{array}$ & ISS, unilateral or bilateral lung contusion, flail chest & $\begin{array}{l}\text { Epidural analgesia } \\
\text { Patient-controlled analgesia } \\
\text { Oral analgesics }\end{array}$ \\
\hline $\begin{array}{l}\text { Linton et al. (1982) } \\
\text { (retrospective cohort) }\end{array}$ & $\begin{array}{l}\text { 26/South } \\
\text { Africa }\end{array}$ & CPAP & $\begin{array}{l}\text { Mechanical } \\
\text { ventilation }\end{array}$ & $\mathrm{PaO}_{2} / \mathrm{FiO}_{2} \geq 150$ & Number of rib fractures, bilateral rib fractures, flail chest & $\begin{array}{l}\text { Epidural analgesia (buprenorphine } \\
\text { and morphine) }\end{array}$ \\
\hline
\end{tabular}

${ }^{a}$ AIS: Abbreviated Injury Score; CPAP, continuous positive airway pressure; ISS: Injury Severity Score; IV, intravenous; NPPV: noninvasive positive pressure ventilation; $\mathrm{PaO}_{2} / \mathrm{FiO}_{2}$ : partial pressure of oxygen to fraction of

inspired oxygen ratio; RCT: randomized controlled trial; TTS: Thorax Trauma Severity Score. 
after respiratory distress had developed in the study participants [7-10]. Accordingly, owing to the differences in the timing of initiation of NIV and the focus on patient safety, we classified these studies into early interventions, late interventions and patient safety assessment categories (Table 1). Analgesia was an integral part of the initial management of these patients. Eight of the studies mentioned the strategies for pain control used in conjunction with NIV (Table 1).

\section{Study quality}

Among the three RCTs, only one [6] was of moderate quality; the other two [20,21] were of low quality because of concerns regarding blinding, allocation and reporting of outcomes (Table 2). The two retrospective cohort studies were considered to be of low quality because of concerns regarding the assessment of outcomes and follow-up in the cohort studies (Table 3). Because of the high risk of selection bias due to the lack of a comparison group and important shortcomings in their reporting of outcomes, we considered observational studies without a comparison group to be of low quality (Table 4).

\section{Safety of noninvasive ventilation in patients with blunt chest trauma}

Table 5 reports the rates of failure of NIV, nosocomial pneumonia, barotrauma and mortality associated with NIV. Four studies assessed the rate of intubation in patients undergoing treatment with NIV at any time during their hospital admission $[6,7,10,20]$. The reported rate of NIV failure ranged from $12 \%$ to $18 \%$. Hurst et al. found a much lower rate of intubation (6\%), but the severity of chest injury in their patients was very low and was not comparable to that reported in the other studies [10]. Gunduz et al. reported no need for intubation in patients undergoing NIV but excluded patients undergoing emergent intubation after randomization from their analysis [20]. If those patients had been included, the rate of intubation would have been $17.1 \%$ [20].

Nosocomial pneumonia and pneumothorax were the most commonly reported adverse events associated with NIV use. Nosocomial pneumonia was reported in five studies, and the rate ranged from $8 \%$ to $13.8 \%$ $[5-7,20,21]$. The rate of pneumothorax reported in two studies ranged from $5.5 \%$ to $24 \%[6,21]$. Of note, the overall event rate for these two aforementioned events was extremely low. Only two studies reported any deaths associated with the use of NIV, which were also low at $4 \%$ and $9 \%[6,20]$.

\section{Noninvasive ventilation compared to high-flow oxygen}

A single study compared NIV to the use of high-flow oxygen therapy ( $\geq 10 \mathrm{~L} / \mathrm{min}$ ) [6]). In this study, patients with ALI and blunt chest trauma were randomized to early NIV or high-flow oxygen therapy. Both groups had similar ISSs and degrees of hypoxemia. The utilization of cointerventions, such as epidurals and patient-controlled analgesia (PCA) for pain control, early chest physiotherapy and need for surgical intervention, was also similar in both groups. Although the study was stopped early, the use of NIV was associated with a lower rate of endotracheal intubation (3 (12\%) of 25 patients vs $10(40 \%)$ of 25 patients; $P=0.02$ ). The need for intubation occurred within the first 24 hours in all the patients in the highflow oxygen group and after 72 hours in all the patients in the NIV group. There were no differences in the rate of pneumothorax, ICU length of stay and mortality.

\section{Noninvasive ventilation compared to endotracheal intubation and mechanical ventilation}

Four studies compared NIV to endotracheal intubation [7-10]. Three studies used CPAP [8-10], and one study used NPPV [7] (Table 6). All of these studies had methodological limitations (Tables 2 through 4). Mortality, ICU length of stay and the rates of nosocomial pneumonia

Table 2 Quality assessment of randomized controlled trials

\begin{tabular}{|c|c|c|c|c|c|c|c|}
\hline & $\begin{array}{l}\text { Selection } \\
\text { bias }\end{array}$ & & Performance bias & $\begin{array}{l}\text { Detection } \\
\text { bias }\end{array}$ & & Attrition bias & $\begin{array}{l}\text { Reporting } \\
\text { bias }\end{array}$ \\
\hline Study & $\begin{array}{l}\text { Random } \\
\text { sequence } \\
\text { generation }\end{array}$ & $\begin{array}{l}\text { Allocation } \\
\text { concealment }\end{array}$ & $\begin{array}{l}\text { Blinding of } \\
\text { participants and } \\
\text { personnel }\end{array}$ & $\begin{array}{l}\text { Blinding for patient } \\
\text { reported outcomes }\end{array}$ & $\begin{array}{l}\text { Blinding for clinical } \\
\text { outcomes } \\
\text { (mortality) }\end{array}$ & $\begin{array}{l}\text { Incomplete } \\
\text { outcome } \\
\text { data }\end{array}$ & $\begin{array}{l}\text { Selective } \\
\text { reporting }\end{array}$ \\
\hline $\begin{array}{l}\text { Hernandez et } \\
\text { al. (2010) }\end{array}$ & Low & Low & Uncertain & Uncertain & Uncertain & Low & Low \\
\hline $\begin{array}{l}\text { Gunduz et al. } \\
\text { (2005) }\end{array}$ & High & High & High & High & High & Uncertain & Uncertain \\
\hline $\begin{array}{l}\text { Bolliger and } \\
\text { Van Eeden } \\
\text { (1990) }\end{array}$ & High & High & High & High & High & Uncertain & Uncertain \\
\hline
\end{tabular}

${ }^{a}$ Studies were considered to be of moderate quality if there were more than two domains with uncertain risk of bias. They were considered to be of low quality if four or more domains had uncertain risk of bias or if one domain had a high risk of bias. 
Table 3 Quality assessment of observational studies

\begin{tabular}{|c|c|c|c|c|c|c|c|c|c|}
\hline \multirow[b]{2}{*}{ Study } & \multirow[b]{2}{*}{$\begin{array}{l}\text { Representation } \\
\text { of the exposed } \\
\text { cohort }\end{array}$} & \multicolumn{2}{|l|}{ Selection } & \multicolumn{2}{|c|}{ Comparability } & \multicolumn{4}{|c|}{ Outcome/exposure } \\
\hline & & $\begin{array}{l}\text { Selection of } \\
\text { non } \\
\text { exposed } \\
\text { cohort }\end{array}$ & $\begin{array}{l}\text { Ascertainment } \\
\text { of exposure }\end{array}$ & $\begin{array}{l}\text { Outcome } \\
\text { not } \\
\text { present at } \\
\text { start }\end{array}$ & $\begin{array}{l}\text { Comparability of } \\
\text { cohorts based on } \\
\text { design or analysis }\end{array}$ & $\begin{array}{l}\text { Assessment } \\
\text { of } \\
\text { outcomes }\end{array}$ & $\begin{array}{l}\text { Time } \\
\text { for } \\
\text { follow- } \\
\text { up }\end{array}$ & $\begin{array}{l}\text { Adequacy } \\
\text { of follow- } \\
\text { up }\end{array}$ & $\begin{array}{l}\text { Overall } \\
\text { score }\end{array}$ \\
\hline $\begin{array}{l}\text { Linton } \\
\text { et al. } \\
\text { (1982) }\end{array}$ & $*$ & * & * & * & - & $*$ & - & - & $\overline{\text { Moderate }}$ \\
\hline $\begin{array}{l}\text { Vidhani } \\
\text { et al. } \\
\text { (2001) }\end{array}$ & * & - & * & * & * & - & - & - & Low \\
\hline
\end{tabular}

${ }^{2}$ Asterisks in each category signify identification of an appropriate methodological process in the study. Studies were considered to be of high quality if less than two components of the Newcastle-Ottawa Scale were missing, fair quality if two or three components were missing and low quality if more than three components were missing.

Table 4 Quality assessment of observational studies with no comparison group. ${ }^{a}$

\begin{tabular}{|c|c|c|c|c|c|c|c|}
\hline \multirow[b]{2}{*}{ Study } & \multicolumn{3}{|l|}{ Selection } & \multicolumn{3}{|c|}{ Exposure/outcome } & \multirow{2}{*}{$\begin{array}{l}\text { Overall } \\
\text { score }\end{array}$} \\
\hline & $\begin{array}{l}\text { Representation of the } \\
\text { exposed cohort }\end{array}$ & $\begin{array}{l}\text { Ascertainment of } \\
\text { exposure }\end{array}$ & $\begin{array}{l}\text { Outcome not } \\
\text { present at start }\end{array}$ & $\begin{array}{l}\text { Assessment of } \\
\text { outcomes }\end{array}$ & $\begin{array}{l}\text { Time for } \\
\text { follow-up }\end{array}$ & $\begin{array}{l}\text { Adequacy of } \\
\text { follow-up }\end{array}$ & \\
\hline $\begin{array}{l}\text { Xirouchaki et } \\
\text { al. (2004) }\end{array}$ & $*$ & $*$ & $*$ & - & - & - & Low \\
\hline $\begin{array}{l}\text { Tanaka et al. } \\
\text { (2001) }\end{array}$ & * & * & - & - & - & - & Low \\
\hline $\begin{array}{l}\text { Walz et al. } \\
\text { (1998) }\end{array}$ & $*$ & $*$ & $*$ & - & - & - & Low \\
\hline $\begin{array}{l}\text { Hurst et al. } \\
\text { (1985) }\end{array}$ & * & * & - & - & - & - & Low \\
\hline
\end{tabular}

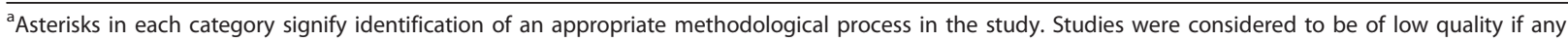
component of the Newcastle-Ottawa Scale was missing, as there was no comparison group, which introduces selection bias at baseline.

Table 5 Outcomes associated with noninvasive ventilation. ${ }^{a}$

\begin{tabular}{|c|c|c|c|c|}
\hline $\begin{array}{l}\text { Study } \\
\text { (design) }\end{array}$ & $\begin{array}{l}\text { Need for intubation due to failure } \\
\text { of noninvasive ventilation }\end{array}$ & Nosocomial infection & Pneumothorax & Mortality \\
\hline $\begin{array}{l}\text { Hernandez et al. (2010) } \\
(\mathrm{RCT})\end{array}$ & $\begin{array}{l}12 \% \text { in NIV vs } 40 \% \text { in high-flow } \\
\text { oxygen group }\end{array}$ & $\begin{array}{l}8 \% \text { in NIV vs } 12 \% \text { in high- } \\
\text { flow oxygen group }\end{array}$ & $\begin{array}{l}24 \% \text { in NIV vs } 12 \% \text { in } \\
\text { high-flow oxygen group }\end{array}$ & $\begin{array}{l}4 \% \text { in NIV vs } 4 \% \text { in high- } \\
\text { flow oxygen group }\end{array}$ \\
\hline $\begin{array}{l}\text { Gunduz et al. (2005) } \\
(\mathrm{RCT})\end{array}$ & $17 \%{ }^{*}$ & $9 \%$ & - & $9 \%$ \\
\hline $\begin{array}{l}\text { Xirouchaki et al. (2004) } \\
\text { (case series) }\end{array}$ & $18 \%$ & $13.6 \% * *$ & - & 0 \\
\hline $\begin{array}{l}\text { Vidhani et al. (2001) } \\
\text { (retrospective cohort) }\end{array}$ & - & - & - & 0 \\
\hline $\begin{array}{l}\text { Tanaka et al. (2001) } \\
\text { (case series) }\end{array}$ & - & - & - & - \\
\hline $\begin{array}{l}\text { Walz et al. (1998) (case } \\
\text { series) }\end{array}$ & - & - & - & 0 \\
\hline $\begin{array}{l}\text { Bolliger and Van Eeden } \\
\text { (1990) (RCT) }\end{array}$ & - & $13.8 \%$ & $5.5 \%$ & 0 \\
\hline $\begin{array}{l}\text { Hurst et al. (1985) (case } \\
\text { series) }\end{array}$ & $6 \%$ & - & - & - \\
\hline $\begin{array}{l}\text { Linton et al. (1982) } \\
\text { (retrospective cohort) }\end{array}$ & - & 0 & - & - \\
\hline
\end{tabular}


Table 6 Outcomes in patients receiving continuous positive pressure ventilation and/or noninvasive positive pressure ventilation compared to mechanical ventilation

\begin{tabular}{|c|c|c|c|c|c|c|c|c|}
\hline \multirow[t]{2}{*}{ Study (design) } & \multicolumn{2}{|c|}{$\begin{array}{l}\text { Duration of } \\
\text { mechanical } \\
\text { ventilation }\end{array}$} & \multicolumn{2}{|l|}{ Mortality } & \multicolumn{2}{|c|}{$\begin{array}{l}\text { Length of stay in ICU/ } \\
\text { hospital }\end{array}$} & \multicolumn{2}{|c|}{ Nosocomial pneumonia } \\
\hline & $\begin{array}{l}\text { CPAP/ } \\
\text { NPPV }\end{array}$ & $\begin{array}{l}\text { Mechanical } \\
\text { ventilation }\end{array}$ & $\begin{array}{l}\text { CPAP/NPPV, } \\
n(\%)\end{array}$ & $\begin{array}{l}\text { Mechanical } \\
\text { ventilation, } n(\%)\end{array}$ & $\begin{array}{l}\text { CPAP/ } \\
\text { NPPV }\end{array}$ & $\begin{array}{l}\text { Mechanical } \\
\text { ventilation }\end{array}$ & $\begin{array}{l}\text { CPAP/NPPV, } \\
n(\%)\end{array}$ & $\begin{array}{l}\text { Mechanical } \\
\text { ventilation, } n(\%)\end{array}$ \\
\hline Gunduz et al. (2005) (RCT) & $\begin{array}{l}15 \pm 4 \\
\text { days }\end{array}$ & - & $2 / 22(9 \%)$ & $7 / 21(33 \%)$ & $16(3)$ & $15(4)$ & $2 / 22(9 \%)$ & $10 / 21(47 \%)$ \\
\hline $\begin{array}{l}\text { Bolliger and Van Eeden } \\
(1990)(R C T))\end{array}$ & $\begin{array}{l}4.5 \pm 2.3 \\
\text { days }\end{array}$ & $\begin{array}{l}7.3 \pm 3.7 \\
\text { days }\end{array}$ & $0 / 36(0)$ & $2 / 33(6 \%)$ & $\begin{array}{l}5.3 \pm 2.9 \\
\text { days }\end{array}$ & $9.5 \pm 4.4$ days & $5 / 36(14 \%)$ & $16 / 33(49 \%)$ \\
\hline $\begin{array}{l}\text { Vidhani et al. (2001) } \\
\text { (retrospective cohort) }\end{array}$ & - & - & $0 / 12(0)$ & $14 / 28(50 \%)$ & $\begin{array}{l}7(3 \text { to } \\
26)\end{array}$ & - & - & - \\
\hline $\begin{array}{l}\text { Linton et al. (1982) } \\
\text { (retrospective cohort) }\end{array}$ & - & - & - & - & $\begin{array}{l}7(3 \text { to } \\
21)\end{array}$ & $12(7$ to 120$)$ & 0 & $5 / 13(38 \%)$ \\
\hline
\end{tabular}

${ }^{a}$ CPAP: Continuous Positive Airway Pressure; NPPV: Noninvasive Positive Pressure Ventilation; RCT: randomized controlled trial. Data are reported as means \pm standard deviation or medians with interquartile range for continuous variables and rates (\%) for all other variables.

were much higher in the intubated patients compared to patients undergoing NIV (Table 6).

Comparisons between the NIV patients and those who were mechanically ventilated were not possible because of important differences in ISS between the two groups. The rates of ISSs and rates of neurological injuries were different in the two groups in studies conducted by Bolligher and Van Eeden [21], Vidhani et al. [19] and Linton et al. [5]. In these studies, patients with severe injuries or decreased levels of consciousness required mechanical ventilation compared to patients with less severe injuries who were treated with NIV. The differences in the need for transfusion of blood products in either of the groups were not mentioned in any of the studies.

\section{Discussion}

Our systematic review assessed the use of NIV for patients with blunt chest trauma. Studies included in our review ranged from moderate (one RCT) to low quality. We found that the application of this modality was highly variable in clinical practice $[6,21,22]$. NIV was instituted mostly when patients had already developed acute respiratory decompensation associated with hypoxemia. Moreover, the timing of initiation of NIV was variable, ranging from a few hours to a few days after hospital admission. In the single RCT, which instituted NIV prior to the development of respiratory failure, intubation rates were low in the patients who had moderate ISSs [6]. The lower rate of intubation in this study may have been due to the early institution of NIV. None of the studies compared CPAP to NPPV. On the basis of the findings of our review, both modalities seem to be safe for use in appropriate patients with blunt chest trauma.

Although there are low- to moderate-quality data on the use of NIV in blunt chest trauma, there may be a role, albeit limited, for the early use of NIV in patients with blunt chest trauma. The RCT data reported by Hernandez et al. suggests that early identification of at-risk patients with prompt institution of NIV in appropriate patients may be of greatest benefit because their NIV failure and mortality rates were lower than those found in the studies where NIV was initiated following the development of respiratory failure [6].

Patients who develop hypoxemic failure later in the course of their hospitalization likely have other factors present, such as progression of lung contusions or the development of pneumonia or ARDS, that result in severe hypoxemia and respiratory distress. Animal studies have shown that lung contusions and associated areas of rib fractures reduce lung compliance, increase shunt fraction and cause capillary leak in the injured and uninjured lung [24,25]. These pathophysiological findings explain the high likelihood of hypoxemic respiratory failure and potential of progression to ARDS in these patients. The rate of failure of NIV in patients with blunt chest trauma who developed acute respiratory distress and respiratory failure in the studies included in our review was very close to the rates reported by Antonelli et al. for any cause of acute hypoxemic respiratory failure $[11,23]$. There is clear evidence that NIV has a limited role in patients with hypoxemic respiratory failure due to ARDS or infection and in fact might be detrimental $[13,26]$. Similarly, our review suggests that a clear role for the use of NIV in blunt thoracic trauma remains uncertain.

When considering a trial of NIV in patients with blunt chest trauma, NIV should be initiated for 48 to $72 \mathrm{~h}$. After the initial stabilization of patients, failure of NIV has been reported mostly following this period [6]. In addition, most of the safety data on the use of NIV derived from observational studies refers to its use within the first 48 to 72 hours after trauma. Thus, for patients 
who are unresponsive to NIV, NIV should be discontinued as soon as possible within the first 24 hours and endotracheal intubation should be considered early to mitigate the potential for harm.

Length of stay in ICU was lower in patients with NIV use compared to invasive mechanical ventilation $[5,20,21]$. In all studies, however, the ventilated patients received continuous sedation, whereas the NIV group received either epidural anesthesia or PCA. As these studies did not use spontaneous breathing trials and sedation interruption, the duration of endotracheal intubation was most likely a major driver of the length of stay in the ICU [27].

A major component of care for patients with blunt chest trauma is the need for adequate pain control. There is convincing evidence for the use of early epidurals, nerve blocks or PCA pumps for these patients [28]. All of these studies judiciously used early epidurals with good pain control along with the use of NIV. In situations where epidurals were not possible or contraindicated, analgesia with nerve blocks and PCA was instituted $[6,7,20,21]$. Unfortunately, this aspect of care for these patients is often overlooked. A close working relationship with the Anesthesia and Pain Control Service might improve the institution of NIV when a patient with blunt chest trauma is being evaluated.

We did not identify any significant morbidity or mortality associated with the use of NIV in patients with blunt chest trauma. Even though the reported mortality was higher in patients undergoing invasive mechanical ventilation compared to NIV, most patients died as a result of their injuries and not as a direct result of respiratory failure. These data reaffirm the need for proper patient selection and the continuous close monitoring of patients being treated with NIV. These patients' conditions can deteriorate very quickly, and their respiratory and overall clinical status should be reassessed often when they are undergoing treatment with NIV.

There are a number of limitations of this systematic review. Studies have reported very heterogeneous clinical data in this field, which is difficult to interpret. We acknowledge that most studies included in this review looked at different modalities, different time periods and also, in some regards (that is, ALI severity and ISSs), different patients. We also have to acknowledge that the progression of respiratory failure may be dependent on nonthoracic injuries and other factors such as transfusion-associated reactions. Even though the studies performed by Bolliger and Van Eeden [21] and Linton et al. [5] had higher ISSs in the intubated patients, there were no differences in the ISSs and trauma patterns between the different groups. We feel, however, that it is critical to highlight this heterogeneity so that clinicians are careful in the way they apply this intervention to patients with blunt chest trauma. It is also important that these limitations are addressed in any future studies addressing this clinical question.

Our study has a number of strengths. We grouped the studies based on the timing of the intervention and the clinical severity of disease. This approach provides a more clear understanding of the utilization of NIV in this population and also highlights the potential pitfalls of using this intervention inappropriately. Our review suggests that the benefit of NIV is early in the course of blunt chest trauma, prior to the development of overt respiratory failure, and that prompt, appropriate institution of this modality can prevent endotracheal intubation. We are able to reaffirm that NIV should be used only in specialized settings by institutions with adequate expertise to handle any complications arising from initiating NIV.

\section{Conclusion}

On the basis of the findings of our review, NIV may be considered in patients with blunt chest trauma who are neurologically intact, hemodynamically stable and not in respiratory distress. There is no apparent benefit of NIV in the prevention of intubation in patients with respiratory decompensation. In fact, delaying intubation in these patients leads to harm. Future studies need to be methodologically sound and focus on the use of NIV in patients with blunt chest trauma early in the course of the disease, prior to overt respiratory failure.

\section{Key messages}

- NIV may be considered in patients with blunt chest trauma who are neurologically intact, hemodynamically stable and not in respiratory distress.

- There is no apparent benefit of NIV in the prevention of intubation in patients with respiratory decompensation.

- NIV should be used only in specialized settings by institutions with adequate expertise to handle any complications arising from initiating NIV.

- The benefit of NIV is early in the course of blunt chest trauma, prior to the development of overt respiratory failure.

- A well-designed, methodologically sound RCT is needed to assess the role of NIV in blunt chest trauma.

\section{Additional material}

Additional File 1: Supplementary File 1: Search Strategy

Additional Files 2: Supplementary File 2: Excluded studies 


\section{Abbreviations}

ALI: acute lung injury; ARDS: acute respiratory distress syndrome; CPAP: continuous positive airway pressure; NIV: noninvasive mechanical ventilation; NPPV: noninvasive positive pressure ventilation; RCT: randomized controlled trial

\section{Competing interests}

This study was not funded. None of the authors have any personal or financial support or involvement with any organization with financial interest in the subject matter or any actual or potential conflict of interest.

\section{Authors' contributions}

$A D$ was involved in the conception and design of the study, analysis of the data and drafting of the article. PP and EG were involved in analysis of the data and revision of the manuscript. TS was involved in the conception of the study and drafting of the article. LT was involved in the design of study, drafting of the article and critical revision of the manuscript. All authors approved the final version of the manuscript.

\section{Acknowledgements}

This work was performed in the Department of Critical Care, Sunnybrook Health Sciences Centre, University of Toronto, Toronto, ON, Canada.

\section{Authors' details}

${ }^{1}$ Medical Intensive Care Unit, Respiratory Institute, Cleveland Clinic Foundation, Euclid Avenue, Cleveland, OH 44195, USA. ${ }^{2}$ Department of Critical Care Medicine, Sunnybrook Health Sciences Centre and University of Toronto, Bayview Avenue, Toronto, ON, M4N 3M5, Canada.

${ }^{3}$ Interdepartmental Division of Critical Care, University of Toronto and Sunnybrook Research Institute, Sunnybrook Health Sciences Centre, Bayview Avenue, Toronto, ON, M4N 3M5, Canada. ${ }^{4}$ Department of Medicine, University Health Network, Bathhurst Street, Toronto, ON, M5T 2S8, Canada. ${ }^{5}$ Department of Surgery, Sunnybrook Health Sciences Centre and University of Toronto, Bayview Avenue, Toronto, ON, M4N 3M5, Canada.

Received: 9 April 2013 Revised: 20 May 2013 Accepted: 22 July 2013 Published: 22 July 2013

\section{References}

1. Klein Y, Cohn SM, Proctor KG: Lung contusion: pathophysiology and management. Curr Opin Anaesthesiol 2002, 15:65-68.

2. Cohn SM, Dubose JJ: Pulmonary contusion: an update on recent advances in clinical management. World J Surg 2010, 34:1959-1970.

3. Nelson LD: Ventilatory support of the trauma patient with pulmonary contusion. Respir Care Clin N Am 1996, 2:425-447.

4. Tyburski JG, Collinge JD, Wilson RF, Eachempati SR: Pulmonary contusions: quantifying the lesions on chest X-ray films and the factors affecting prognosis. J Trauma 1999, 46:833-838.

5. Linton DM, Potgieter PD: Conservative management of blunt chest trauma. S Afr Med J 1982, 61:917-919.

6. Hernandez G, Fernandez R, Lopez-Reina P, Cuena R, Pedrosa A, Ortiz R, Hiradier $P$ : Noninvasive ventilation reduces intubation in chest traumarelated hypoxemia: a randomized clinical trial. Chest 2010, 137:74-80.

7. Xirouchaki N, Kondoudaki E, Anastasaki M, Alexopoulou C, Koumiotaki S, Georgopoulos D: Noninvasive bilevel positive pressure ventilation in patients with blunt thoracic trauma. Respiration 2005, 72:517-522.

8. Tanaka H, Tajimi K, Endoh Y, Kobayashi K: Pneumatic stabilization for flail chest injury: an 11-year study. Surg Today 2001, 31:12-17.

9. Walz M, Möllenhoff G, Muhr G: [CPAP-augmented spontaneous respiration in thoracic trauma: an alternative to intubation] [in German]. Unfallchirurg 1998, 101:527-536.

10. Hurst JM, DeHaven CB, Branson RD: Use of CPAP mask as the sole mode of ventilatory support in trauma patients with mild to moderate respiratory insufficiency. J Trauma 1985, 25:1065-1068.

11. Antonelli M, Conti G, Rocco M, Bufi M, De Blasi RA, Vivino G, Gasperetto A Meduri GU: A comparison of noninvasive positive-pressure ventilation and conventional mechanical ventilation in patients with acute respiratory failure. N Engl J Med 1998, 339:429-435.

12. British Thoracic Society Standards of Care Committee: Non-invasive ventilation in acute respiratory failure. Thorax 2002, 57:192-211.

13. Keenan SP, Sinuff T, Burns KE, Muscedere J, Kutsogiannis J, Mehta S Cook DJ, Ayas N, Adhikari NK, Hand L, Scales DC, Pagnotta R, Lazosky L,
Rocker G, Dial S, Laupland K, Sanders K, Dodek P, Canadian Critical Care Trials Group/Canadian Critical Care Society Noninvasive Ventilation Guidelines Group: Clinical practice guidelines for the use of noninvasive positive-pressure ventilation and noninvasive continuous positive airway pressure in the acute care setting. CMAJ 2011, 183:E195-E214.

14. Baker SP, O'Neill B, Haddon W Jr, Long WB: The Injury Severity Score: a method for describing patients with multiple injuries and evaluating emergency care. J Trauma 1974, 14:187-196.

15. Lee JY, Vaccaro AR, Lim MR, Öner FC, Hulbert RJ, Hedlund R, Fehlings MG, Arnold P, Harrop J, Bono CM, Anderson PA, Anderson DG, Harris MB, Brown AK, Stock GH, Baron EM: Thoracolumbar Injury Classification and Severity Score: a new paradigm for the treatment of thoracolumbar spine trauma. J Orthop Sci 2005, 10:671-675.

16. Bernard GR, Artigas A, Brigham KL, Carlet J, Falke K, Hudson L, Lamy M, LeGall JR, Morris A, Spragg R, the Consensus Committee: Report of the American-European Consensus Conference on ARDS: definitions, mechanisms, relevant outcomes and clinical trial coordination. Intensive Care Med 1994, 20:225-232

17. Higgins JPT, Green S: Cochrane Handbook for Systematic Reviews of Interventions The Cochrane Collaboration; 2011 [http://www.cochranehandbook.org/], Version 5.1.0 [updated March 2011].

18. Stang A: Critical evaluation of the Newcastle-Ottawa Scale for the assessment of the quality of nonrandomized studies in meta-analyses. Eur J Epidemiol 2010, 25:603-605.

19. Vidhani K, Kause J, Parr M: Should we follow ATLS guidelines for the management of traumatic pulmonary contusion: the role of noninvasive ventilatory support. Resuscitation 2002, 52:265-268.

20. Gunduz M, Unlugenc H, Ozalevli M, Inanoglu K, Akman H: A comparative study of continuous positive airway pressure (CPAP) and intermittent positive pressure ventilation (IPPV) in patients with flail chest. Emerg Med J 2005, 22:325-329.

21. Bolliger CT, Van Eeden SF: Treatment of multiple rib fractures: randomized controlled trial comparing ventilatory with nonventilatory management. Chest 1990, 97:943-948.

22. Vital FM, Saconato H, Ladeira MT, Sen A, Hawkes CA, Soares B, Burns KE, Atallah AN: Non-invasive positive pressure ventilation (CPAP or bilevel NPPV) for cardiogenic pulmonary edema. Cochrane Database Syst Rev 2008, 3, CD005351.

23. Antonelli M, Conti G, Moro ML, Esquinas A, Gonzalez-Diaz G, Confalonieri M, Pelaia P, Principi T, Gregoretti C, Beltrame F, Pennisi MA, Arcangeli A, Proietti R, Passariello M, Meduri GU: Predictors of failure of noninvasive positive pressure ventilation in patients with acute hypoxemic respiratory failure: a multi-center study. Intensive Care Med 2001 27:1718-1728.

24. Craven KD, Oppenheimer L, Wood LD: Effects of contusion and flail chest on pulmonary perfusion and oxygen exchange. J Appl Physiol 1979, 47:729-737.

25. Raghavendran K, Notter RH, Davidson BA, Helinski JD, Kunkel SL, Knight PR: Lung contusion: inflammatory mechanisms and interaction with other injuries. Shock 2009, 32:122-130.

26. Jolliet $P$, Abajo B, Pasquina $P$, Chevrolet JC: Non-invasive pressure support ventilation in severe community-acquired pneumonia. Intensive Care Med 2001, 27:812-821.

27. Girard TD, Kress JP, Fuchs BD, Thomason JWW, Schweickert WD, Pun BT, Taichman DB, Dunn JG, Pohlman AS, Kinniry PA, Jackson JC, Canonico AE, Light RW, Shintani AK, Thompson JL, Gordon SM, Hall JB, Dittus RS, Bernard GR, Ely EW: Efficacy and safety of a paired sedation and ventilator weaning protocol for mechanically ventilated patients in intensive care (Awakening and Breathing Controlled trial): a randomised controlled trial. Lancet 2008, 371:126-134.

28. Carrier FM, Turgeon AF, Nicole PC, Trépanier CA, Fergusson DA, Thauvette D, Lessard MR: Effect of epidural analgesia in patients with traumatic rib fractures: a systematic review and meta-analysis of randomized controlled trials. Can J Anaesth 2009, 56:230-242.

doi:10.1186/cc12821

Cite this article as: Duggal et al:: Safety and efficacy of noninvasive ventilation in patients with blunt chest trauma: a systematic review. Critical Care 2013 17:R142. 